Богатырева С.Н.

DOI: 10.7256/2305-560X.2014.4.12212

\title{
ПАТРИОТИЗМ РОССИЙСКОГО ЗАРУБЕЖЬЯ И ЭМИГРАЦИИ
}

\begin{abstract}
Аннотация: В статье речь идет о трактовке понятия "патриотизм» как особом способе концептуализаиии действительности представителями российского и русского Зарубежья и эмиграции. Рассматривается и анализируется содержание деятельности эмигрантов за рубежом в послереволючионный период и годы Второй мировой войны.В 2012 году исполнилось 90 лет событию, сыгравшему огромную отрицательную роль в судьбе России, и связано оно с изгнанием из страны после Великой Октябрьской социалистической револючии, разгрома интервенции и внутренней контрреволюции, выдающихся людей своей эпохи: просветителей, философов, ученых, врачей, деятелей искусства, поэтов, писателей, высокопрофрессиональных специалистов и общественных деятелей, гуманистов, мыслителей. Они были изгнаны только за то, что отстаивали принцип духовной свободы в своей жизни и творчестве, и были признаны Советской властью безнадежными в смысле обращения в коммунистическую веру. Это было изгнание, осуществленное новой властью не по политическим, а по идеологическим причинам.
\end{abstract}

Ключевые слова: международные отношения, внешняя политика, Россия, русская эмиграция, культурная миссия эмиграции, российская эмиграция, патриотизм, "философский пароход», русский патриот, истинный патриот.

$\mathrm{B}$ 2012 году исполнилось 90 лет событию, сыгравшему огромную отрицательную роль в судьбе России, и связано оно с изгнанием из страны после Великой Октябрьской социалистической революции, разгрома интервенции и внутренней контрреволюции, выдающихся людей своей эпохи: просветителей, философов, ученых, врачей, деятелей искусства, поэтов, писателей, высокопрофессиональных специалистов и общественных деятелей. Они были изгнаны только за то, что отстаивали принцип духовной свободы в своей жизни и творчестве, и были признаны Советской властью безнадежными в смысле обращения в коммунистическую веру. Это было изгнание не по политическим, а по идеологическим причинам.

Контрреволюционная эмиграция всегда была следствием больших социальных переворотов, когда в ходе революционной борьбы новые общественные силы приходят к власти. Объясняя причины массового бегства из России интеллигенции, историк и богослов Г. Федотов писал: «С самого начала большевизм поставил своей целью перековать народное сознание, создать в новой России на основе марксизма совершенно новую, «пролетарскую» культуру. В неслыханных размерах был предпринят опыт государственного воспитания нового человека, лишенного религии, личной морали и национального сознания, - опыт, который дал известные результаты: обездушение и обезличение новой России - факт несомненный...».
Интеллигенция не могла не отнестись критически к проводимой политике, и стала рассматриваться Советской властью как опасный враг. Попытка большевиков «приручить» ее и сделать послушной окончилась неудачей. Тогда было принято решение избавиться от наиболее значительных ее представителей путем насильственной высылки из страны. Эта суровая мера была применена к русской интеллигенции в 1922-1923 гг.

Большевики не считали интеллигенцию опасной для себя политической силой. Л. Троцкий писал в «Известиях»: «Те элементы, которые мы высылаем или будем высылать, сами по себе политически ничтожны. Но они - потенциальные орудия в руках наших возможных врагов». Захватив единоличную власть после Октябрьского переворота и разгона Учредительного собрания, большевики не чувствовали себя уверенно, понимая, что их власть незаконна, и боялись потерять ее. Они установили «диктатуру пролетариата», которая в действительности была диктатурой партийной номенклатуры и только прикрывались лозунгом «диктатура пролетариата», и старались искоренить инакомыслие. Их целью было очистить страну от людей, способных самостоятельно мыслить и анализировать и несогласных с их политикой; кардинально пресечь свободомыслие и критику власти. Интеллигенция, которая долгие годы готовила революцию, рассчитывая, что она даст народу свободу и справедливость, не могла примириться с крушением своих надежд. 
Высылались по распоряжению В. И. Ленина, без суда и следствия, потому что не за что было судить: отстаивание свободы мысли, отказ от навязываемого сверху единомыслия не были предметом суда. «Мы этих людей выслали потому, что расстрелять их не было повода, а терпеть было невозможно» (Л. Троцкий). Главной целью высылки было запугать интеллигенцию и заставить ее молчать. Это было предостережением: не выступать против власти.

Раскрытия содержания деятельности эмигрантов за рубежом в послереволюционный период требует использования специальных понятий, обозначенных терминами. Поэтому представляется необходимым уточнить смысловое значение терминов с тем, чтобы позволить читателю получить целостную картину излагаемой проблемы и разобраться во взаимосвязях между ключевыми понятиями, которыми мы будем оперировать в настоящей работе. Термин «русская эмиграция» используется для обозначения этнических русских в странах проживания. Понятие «российская эмиграция» подразумевает всех выходцев из России, независимо от их этнической принадлежности, а термин «белая эмиграция» обозначает всех эмигрантов, не принявших советской власти после революции 1917 г.

Символом эмиграции русской интеллигенции стал собирательный образ «Философского парохода», возникший в результате того, что пароход служил не только транспортным средством, на котором уезжали изгнанники, но и потому, что среди его пассажиров были подвергшиеся преследованию и высылке представители интеллектуальной русской элиты.

Первый пароход - его название не сохранилось - отвез из Одессы в Константинополь троих высланных: профессоров Б.П. Бабкина и А.В. Флоровского и ассистента Г.А. Секачева. Второму кораблю выпала честь в четверг вечером 28 сентября принять на борт московскую группу изгнанников «в составе 24 человек (с семьями 84)». Это был «Oberburgermeister Haken» - комфортабельный, правда, уже не новый, но все еще элегантный, оснащенный электрическим освещением, скоростной пароход класса А I и водоизмещением 1250 тонн, принадлежавший Stettiner Dampfer-Compangie и выполнявший рейс Петроград - Штеттин. Третьему пароходу под названием «Preussen» той же пароходной компании и, по-видимому, того же класса пришлось сделать несколько рейсов с высланными на борту. 16 ноября, «Пройссен» забрал из Петро- града питерскую группу из 17 человек высланных с членами их семей и, как минимум, четверых добровольных эмигрантов (всего 44 человека) и в воскресенье утром, т.е. с небольшим опозданием, доставил их в Штеттин: переезд из Петрограда в Штеттин обычно занимал два дня. В ночь с 15 на 16 декабря «Пройссен» взял на борт высланного писателя-беллетриста В.Я. Ирецкого. А 17 февраля 1923 г. газета «Руль» сообщила, что на «Пройссене» находится вместе со своей семьей высланный редактор журнала «Экономист» Д.А. Лутохин. 0 четвертом корабле под названием «Јеапnе» известно, что этот итальянский пароход увез 27 декабря 1922 г. из Севастополя в Константинополь высланного религиозного мыслителя С.Н. Булгакова с семьей. Был и пятый пароход, на борту которого пересекли Черное море и прибыли 11 февраля 1922 г. из Одессы в Варну три профессора Новороссийского университета, высланные по так называемому украинскому списку ${ }^{1}$.

Высылались за рубеж также поездами: из Москвы в Латвию и Германию, а также через Польшу, Финляндию и афганскую границу - в другие страны. Они везли уникальный груз - цвет русской интеллигенции, славу России: профессоров и философов с мировым именем, чьи труды в Европе и во всем мире считались вершиной философской и научной мысли; учителей, врачей и других представителей русской интеллигенции.

Среди изгнанных был один из самых блестящих философов России XX века Н. А. Бердяев; известные философы: С. Л. Франк, Л. П. Карсавин, Н. О. Лосский, С.Н. Булгаков, В.А. Боголепов, И.А. Ильин, Ф. А. Степун, Н.С. Трубецкой, И.И. Лапшин; историк А.В. Флоровский, физиолог Б.П. Бабкин, писатель М. Осоргин. Были там передовые, прогрессивные профессора и руководители высших учебных заведений и школ, в том числе ректоры Московского и Петроградского университетов. В 1921 году были также арестованы все члены Помгола - Всероссийского комитета помощи голодающим, а затем высланы его создатели и наиболее активные члены: С. Прокопович и Е. Кускова. Эта организация, действенно помогавшая людям и тем завоевавшая авторитет у населения, показалась опасной. Ее членам были предъявлены необоснованные обвинения в шпионаже - репрессивная тактика, «успешно» подхваченная и развитая позд-

Дмитриева Н. - Электронный код доступа [URL: http:// scepsis.net/authors/id_92.html;http://yadocent.livejournal. com/344839.html] 


\section{Международные отношения / International Relations / № 4/2014}

нее И. Сталиным. Таким образом, большевистская власть активно освобождалась от независимо мыслящей интеллигенции, которая не являлась ее политическим противником и не имела намерения бороться за власть.

Сначала большинство изгнанников оказалось в Германии, но со временем почти все они перебрались в Париж, ставший центром русской эмиграции. Благодаря своему высокому интеллектуальному и профессиональному уровню все вынужденные эмигранты не только нашли возможность работать по специальности, но создали культурные и научные ценности, которые стали достоянием Европы и Америки. Так, Н.А. Бердяев был признан ведущим мыслителем Европы и оказал большое влияние на развитие европейской философии; П.А. Сорокин, известный ученый-социолог, стал профессором Гарвардского университета и основоположником американской социологии; С.Л. Франк, русский религиозный философ, внес большой вклад в развитие социальной психологии и гносеологии; выдающийся ученый - лингвист и литературовед Р. О. Якобсон стал профессором Гарвардского университета. Очевидно, что все эти и многие другие замечательные ученые-эмигранты русского происхождения сделали огромный вклад и обогатили науку, технику и экономику стран, где они жили, основали новые научные направления, послужили подъему престижа этих стран.

Самое удивительное, что высланные эмигранты ощущали свою миссию сохранить русскую культуру, чтобы вернуть ее в Россию, когда закончится этот «большевистский кошмар», а то, что он закончится - и скоро, верило большинство эмигрантов. Они готовились к возвращению на родину и готовили к этому новое поколение. Философские сочинения и политические публикации объединяла идея культурной миссии эмиграции.

Слова знаменитого литератора русского зарубежья Романа Гуля «Мы не покинули Россию, мы унесли ее с собой» стали лейтмотивом большинства интеллектуальных сил русской эмиграции. Та же неразрывная связь с Родиной у В. Ходасевича: «А я с собой мою Россию / В дорожном уношу мешке / Вам нужен прах отчизны грубый, / А я где б ни был - шепчут мне /Арапские святые губы / О небывалой стороне». Культура в этой ситуации «посланности», исполнения исторической миссии приобретала исключительное значение.

Культурная и научная жизнь эмиграции была довольно сложной и противоречивой. Эта тема требует специального изучения, анализа и объек- тивной оценки. Обращая внимание только на культурные достижения русских за рубежом, некоторые эмигрантские авторы находились под влиянием своего рода эмигрантского патриотизма, который, как правильно заметил Л.Д. Любимов, «лишь кривое зеркало подлинной национальной гордости» ${ }^{2}$.

Четверть века находился в эмиграции выдающийся русский мыслитель и писатель Н.Н. Бердяев. Наследуя традицию славянофилов и западников, П. Чаадаева и А. Хомякова, А. Герцена и В. Белинского, М.Бакунина и Н. Чернышевского, несмотря на различие миросозерцаний, и более всего Ф. Достоевского и Л. Толстого, Вл. Соловьева и Н. Федорова, он всегда ощущал себя частью русской интеллигенции, искавшей правду. Он не находил противоречия в том, что многие называли его «выразителем аристократизма социализма», более того, он сам сознавал себя «мыслителем аристократическим, признававшим правду социализма». В своей автобиографии «Самопознание» Н.Н. Бердяев выразил суть того, что не могла принять интеллигенция: «Что я противопоставлял коммунизму?.. Я противопоставлял, прежде всего, принцип духовной свободы, для меня изначальный, абсолютный, который нельзя уступить ни за какие блага мира. Я противопоставлял также принцип личности как высшей ценности, ее независимость от общества и государства, от внешней среды... Это совсем не значит, что я антисоциалист. Я сторонник социализма, но мой социализм персоналистический, не авторитарный...» ${ }^{3}$.

По воспоминаниям самого Бердяева, группа высланных из России ученых в сентябре 1922 г. в количестве 25 человек с членами их семей (всего 75 человек), направлялась на нанятом пароходе «Oberburgermeister Haken» из Петербурга в Штеттин (Германия). Первые тяжелые впечатления в Германии у Бердяева были связаны со столкновениями с представителями русской эмиграции, во главе которой стоял П. Струве. Подавляющее большинство эмигрантов встретили группу высланных подозрительно и недоброжелательно, считая, что Советская власть их подослала с целью разложения эмиграции.

За границей Н. Бердяев много пишет о русской революции и коммунизме, он старается быть выше борьбы противодействующих сторон, увидеть не

\footnotetext{
2 Шкаренков Л. - Электронный код доступа [URL: http:// scepsis.net/library/id_2136.html]

Бердяев Н. Самопознание / Николай Бердяев. - М.: АСТ: Астрель: Политграфиздат, 2010. - 447, [1] с. - (Философия. Психология).
} 
только ложь, но и правду коммунизма. Одним из основных мотивов его христианской деятельности на Западе стало понимание коммунизма как напоминание «о неисполненном христианском долге»". По его убеждению, именно христиане должны были осуществить правду коммунизма, и тогда не восторжествовала бы ложь коммунистической идеологии. Поэтому он воспринимал коммунизм не только как кризис христианства, но и как кризис гуманизма.

Наблюдая настроения русской эмиграции в Западной Европе, Бердяев, один из немногих, причислял себя к тому числу людей, которые были свободны от "ressentiment" по отношению к коммунизму в период русской революции, пытался осмыслить значение этого исторического события не только для судьбы России, но и для судьбы всего мира.

В отличие от большинства представителей эмиграции правого уклона, принадлежавших к так называемому белому движению, Н. Бердяев расходился с преобладающим в эмиграции общественным мнением о свержении большевизма путем интервенции и вмешательстве иностранцев в русскую судьбу. Более того, Н. Бердяев не верил в белое движение, считал его безвозвратно ушедшим в прошлое и лишенным всякого значения и даже вредным. Он был убежден, что вся вина и ответственность за ужасы революции лежала, прежде всего, на реакционных силах старого режима и людях этого режима и, следовательно, не им быть судьями этих катастрофических исторических потрясений и тяжелейших разрушительных последствий для судьбы России. Тип «белого» эмигранта с его «каменной нераскаянностью», отсутствием сознания своей вины и, наоборот, гордое сознание своего пребывания в правде, вызывал у него отталкивание и неприятие. К нему приходит полное осознание того, что «ответственность за духоборческий, враждебный характер русской революции лежит на деятелях русского ренессанса начала XX века» 5 .

Прожив долгие годы изгнания на Западе, и побывав во многих странах, Н. Бердяев часто обращал свой взор на Россию, и именно взор на Россию из Запада, что давало ему острое чувство сопоставления разных миров. Наблюдая разные национальности Европы, их настроения и образ мышления,

4 Бердяев Н. Самопознание / Николай Бердяев. - М.: АСТ: Астрель: Политграфиздат, 2010. - 447, [1] с. - (Философия. Психология). С. 290.

5 Бердяев Н. Самопознание / Николай Бердяев. - М.: АСТ: Астрель: Политграфиздат, 2010. - 447, [1] с. - (Философия. Психология). С. 289. он положительно отзывался о многих людях и народах, но в то же время с глубоким отвращением и возмущением высказывался относительно «царившего повсюду в Европе национализма»; он считал его аморальным, глупым и смешным, и сравнивал его с индивидуальным эгоцентризмом ${ }^{6}$. По его признанию, в изгнании у него только нарастала страстная любовь к России и русскому народу, вера в великую, «универсалистическую миссию» русского народа. В своих воспоминаниях Н. Бердяев пишет, что органический универсализм - это характерное свойство его собственной натуры, и эта черта непосредственно связана с его персонализмом. И далее он приходит к заключению, что «этот универсализм вполне соединим с патриотизмом и народностью» ${ }^{7}$. Сам о себе Бердяев говорил, что его универсализм, его неприятие национализма в любом проявлении - это исконно русская черта: «Я не националист, но русский патриот. Я также противник самомнения и самоутверждения европеизма и защищаю русский восток» ${ }^{8}$. Будучи яростным противником засилия национализма, грозившей гибелью Европе, Бердяев готов был защищать даже интернационализм, поскольку в нем была извращенная правда универсализма. Отдавая должное интеллектуальному и культурному благополучию Европы, тем не менее, он пишет: «У меня всегда было чувство, что этот высоко культурный и свободолюбивый мир висит над бездной и будет свержен в эту бездну катастрофой войны или революции» ${ }^{9}$. Бердяев убежден, что существует единственный способ предотвратить крушение Европы. Это станет возможным, если европейское общество найдет в себе силы выйти из своего перманентного состояния «буржуазного самодовольства», и перестанет наслаждаться внешним существованием; европейцам пришло время почувствовать «зов духовной глубины» ${ }^{10}$.

6 Там же.

7 Бердяев Н. Самопознание / Николай Бердяев. - М.: АСТ: Астрель: Политграфиздат, 2010. - 447, [1] с. - (Философия. Психология). С. 340.

8 Бердяев Н. Самопознание / Николай Бердяев. - М.: АСТ: Астрель: Политграфиздат, 2010. - 447, [1] с. - (Философия. Психология). С. 340.

9 Бердяев Н. Самопознание / Николай Бердяев. - М.: АСТ: Астрель: Политграфиздат, 2010. - 447, [1] с. - (Философия. Психология).С. 345

10 Бердяев Н.А. Философия творчества, культуры, искусства. Т.2. В 2-х т. М.: Искусство,1994. - 510с. (Серия «Русские философы ХХ века). С. 150. 


\section{Международные отношения / International Relations / № 4/2014}

Идеологически Н. Бердяев не принимал советскую власть, запятнавшую себя бесчеловечием и жестокостью, и относился к ней крайне отрицательно. По его признанию, с коммунизмом он вел не политическую, а духовную борьбу, борьбу против его духа, против его вражды к духу. Вместе с тем, он считал, что именно эта власть как организованная сила способна защитить Россию от грозящих ей опасностей в данный исторический период: «Советская власть есть не только власть коммунистической партии, претендующей осуществить социальную правду, она есть также государство $\langle\ldots>$, она заинтересована в защите государства и в его экономическом развитии, без которого власть может пасть» ${ }^{11}$. В это время в России идет этап формирования не только коммунистического, но и советского патриотизма, который Н. Бердяев детерминирует как «просто русский патриотизм». Поддерживая становление патриотизма в советской России, и считая его положительным фактом, он противопоставляет его национализму и предостерегает, что последний может принять самые отрицательные формы.

Вот как Н. Бердяев на страницах «Русский коммунизм и революция» формулирует высший смысл патриотизма и соотносит его с мессианским предназначением России, русского народа: «nатриотизм великого народа должен быть верой в великую миссию этого народа, иначе это будет национализм провинциальный, замкнутый и лишенный мировых перспектив» ${ }^{12}$. В таком мессианском сознании, как пишет Н. Бердяев, изначально отсутствует национальная исключительность и национальный партикуляризм.

Необходимо отметить, что обращенность к судьбе покинутой Родины, ее будущности, особому мессианскому призванию России стали доминирующими мотивами в трудах большинства российской эмигрантской интеллектуальной элиты.

Достаточно показательно в этом смысле творчество выдающегося русского философа и патриота И.А. Ильина. Центральное место в его философских размышлениях занимают проблемы России, пути духовного и социального возрождения Роди-

11 Бердяев Н.А. Сочинения./Сост., вступ. статья и прим. А.В. Гулыги. - М.: «Раритет», 1994. - 416с. - (Библиотека духовного возрождения). С. 374.

12 Бердяев Н.А. Сочинения./Сост., вступ. статья и прим. А.В. Гулыги. - М.: «Раритет», 1994. - 416с. - (Библиотека духовного возрождения). C. 374 ны, защита нравственных и духовных ценностей. Все эти вопросы как никогда актуальны и в настоящее время.

В своих размышлениях Ильин приходит к убеждению о том, что первые проблески правосознания, «верности» и «патриотического настроения» возникают у человека из чувства солидарности со своими ближними. Когда человек соединяет свою судьбу с судьбою своего народа, как в самые опасные минуты своей жизни, так и в эпоху благоденствия, в его достижении и в его падении, этот человек становится истинным naтриотом. По И. Ильину, < ...истинный патриот отождествляет себя инстинктом и духом не с множеством различных и неизвестных ему «человеков», среди которых, наверное, есть и злые, и жадные, и ничтожные, и предатели; он не сливается с жизнью темной массы, которая в дни бунта бывает, по бессмертному слову Пушкина, «бессмысленна и беспощадна»; он не приносит себя в жертву корыстным интересам бедной или роскошествующей черни (ибо чернью называется вообще жадная, бездуховная, противогосударственная масса, не знающая родины или забывающая ее) он отнюдь не преклоняется перед «множеством» только потому, что на его стороне количество, и не считает, что большинство всегда одарено мудрою и безошибочною волею. Нет; он сливает свой инстинкт и свой дух с инстинктом и с духом своего народа; и духовности своего народа он служит жизнью и смертью, ибо его душа и его тело естественно и незаметно следуют за совершившимся отождествлением» ${ }^{13}$.

Поскольку любовь к родине должна быть духовно оправдана и обоснована человеком, «патриотизм» оказывается «неизбежным, целесообразным и жизненно-полезным...» ${ }^{14}$. Как считает И. Ильин, в этом и заключается жизненно-бытовая польза патриотизма.

В понимании И. Ильина, патриотизм есть чувство любви к родине, именно поэтому, как и всякое чувство, а особенно чувство любви, он уходит корнями в глубину человеческого бессознательного, в жилище инстинкта и страстей, куда далеко не каждый имеет доступ. И только степень духовного опыта и сила духовного видения может открыть человеку этот доступ. «Патриотизм,

13 Ильин И.А. Пути России / Иван Ильин; сост. А.Д. Путинцев. - М.: Вагриус, 2007. С. 180

14 Ильин И.А. Пути России / Иван Ильин; сост. А.Д. Путинцев. - М.: Вагриус, 2007. С. 162. 
как состояние радостной любви и вдохновенного творчества, есть состояние духовное; и потому он может возникнуть только в порядке $а в$ тономии (свободы), - в личном, но в подлинном и предметном духовном опыте» ${ }^{15}$. Точно так же, как любовь возникает сама по себе, легко, непринужденно и осеняет человека, точно также происходит зарождение чувства патриотизма, когда человек не тяготится этим чувством, а радуется своему счастью.

Истинный, духовный патриотизм Ильин противопоставляет так называемому «казенному», внешнепринудительному, официальному патриотизму, который далеко не всегда пробуждает и воспитывает в душе чувство родины и может даже повредить его. В основе патриотического единения людей лежит их сопринадлежность - сходное переживание единого и общего духовного предмета, духовное подобие родит духовное единство. Этот процесс духовного «симбиоза» является источником и новых творческих усилий, и новых достижений, и нового уподобления. Таким образом, патриотическое единение есть разновидность духовного единения, которое вырабатывается исторически, в борьбе с природой, в создании единой духовной культуры и в самообороне от вторгающихся нарушителей. Закрепляется такое единство своеобразием национально-духовного акта и системой историческикультурных и государственно-хозяйственных задач в определенный период времени. И. Ильин пишет: «Каждый народ призван принять свою природную и историческую «данность» и духовно проработать ее, одолеть ее, одухотворить ее по-своему, пребывая в своем, своеобразном национально-творческом акте. Это его неотъемлемое, естественное, священное право; и в то же время это его историческая, общечеловеческая и, что самое главное, религиозная обязанность» ${ }^{16}$. Такое слияние патриота с его родиной ведет к плодотворному отождествлению взаимных духовных энергий. В этом отождествлении духовная жизнь народа укрепляется всеми личными силами патриота, а патриот, в свою очередь, получает неиссякаемый источник творческой энергии во всенародном творческом подъеме. Именно это взаимное духовное питание и обогащение, мно-

15 Ильин И.А. Пути России / Иван Ильин; сост. А.Д. Путинцев. - М.: Вагриус, 2007. С.181-182.

16 Ильин И.А. Пути России / Иван Ильин; сост. А.Д. Путинцев. - М.: Вагриус, 2007. С. 183-189 гократно возвращаясь и удесятеряя силы, дает человеку непоколебимую веру в его родину ${ }^{17}$.

Итак, рассуждая о взаимообусловленности идеи родины и чувства патриотизма, Ильин показал не только их неизбежность и естественность в историческом развитии народов, не просто их государственное значение и их культурную продуктивность, но их религиозную священность.

Примером такого рода подъема патриотических чувств может служить поведение большинства представителей прогрессивной русской эмиграции в 1941 году, когда Германия открыто пошла на Россию. Несмотря на то, что эмиграция была разнородна, часть ее придерживалась линии «невмешательства» в политику, вернее, питалась иллюзиями на этот счет, и сходилась в одном: во враждебном отношении к Советской власти, считая ее главным злом, и желала победы Германии, надеясь, что это «вернет России возможность собой располагать». Но большинство считало такую победу, даже на короткое время, величайшим злом для России. Некоторые ученые-специалисты из числа эмигрантов еще в первые годы эмиграции встали не только на путь признания Советской власти, но даже примкнули к сменовеховскому движению. Так, например, крупный ученый-микробиолог С.С. Чахотин был в числе авторов сборника «Смена вех». Через много лет он вернулся в Советский Союз, а в годы второй мировой войны за рубежом был активным антифашистом, участвовал в движении Сопротивления.

По воспоминаниям В.А. Маклакова, в прошлом один из лидеров кадетской партии, бывший посол Временной» правительства во Франции: «Действительные события оказались для всех откровением. Мы не предвидели, насколько за годы нашего изгнания Россия окрепла. Победоносная Германия принуждена была перед ней отступить. Мы восхищались патриотизмом народа, доблестью войск, искусством вождей. Но должны были признать, кроме того, что все это подготовила Советская власть, которая управляла Россией, что в ее руках исход этой войны. Это меняло наше прежнее отношение к ней...» ${ }^{18}$.

Н.Н. Бердяев также обращал внимание, что в советской России сейчас говорят о социалистическом отечестве и его хотят защищать, во имя него

\footnotetext{
17 Ильин И.А. Пути России / Иван Ильин; сост. А.Д. Путинцев. - М.: Вагриус, 2007. С.192.

18 Шкаренков Л. - Электронный код доступа [URL: http:// scepsis.net/library/id_2136.html]
} 
готовы жертвовать жизнью. Опасность со стороны Германии и Японии только способствовала укреплению русского патриотизма ${ }^{19}$.

Можно сказать, что нападение фашистской Германии на Советский Союз стало своего рода лакмусовой бумажкой, выявившей отношение эмиграции и разных ее представителей к своей родине в годину грозной для нее опасности. В результате обнаружился широкий спектр настроений и действий - от выступлений откровенных коллаборационистов, сотрудничавших с фашистами, до активного участия в движении Сопротивления.

Уже летом 1940 г. русские эмигранты приняли участие в первых подпольных организациях французского Сопротивления. Активными участниками первой организации Сопротивления оккупантам стали Борис Вильде и Анатолий Левицкий - сыновья русских эмигрантов, молодые ученыеэтнографы «Музея человека» в Париже. «Группа музея человека», как называли эту организацию, выпустила нелегальную газету «Резистанс» («Сопротивление»), название которой потом перешло ко всему антифашистскому движению во Франции. Газета призывала создавать подпольные группы сопротивления, вербовать решительных и верных людей, готовиться к вооруженной борьбе с гитлеровцами.

О героях французского Сопротивления Б. Вильде и А. Левицком написаны воспоминания, сняты фильмы. Их имена выбиты на мраморной доске в «Музее человека» в Париже. Там же помещены тексты приказов генерала де Голля, подписанных в Алжире 3 ноября 1943 г., о посмертном награждении Б. Вильде и А. Левицкого медалью Сопротивления. В приказах отмечены их научные заслуги, героизм и самопожертвование во имя победы над фашизмом.

У некоторых эмигрантов с самого начала была твердая уверенность в поражении гитлеровской Германии. Эта уверенность в победе, пусть сначала интуитивная, эмоциональная, в тех условиях была важным элементом, моральное влияние которого все больше возрастало. По воспоминаниям многих бывших эмигрантов ими руководило, скорее всего, иррациональное, унаследованное от отца и матери древнее чувство, воспитанное всей русской литературой и богатейшей историей страны: Россия непобедима, русский народ не-

19 Бердяев Н.А. Сочинения./Сост., вступ. статья и прим. А.В. Гулыги. - М.: «Раритет», 1994. - 416с. - (Библиотека духовного возрождения). С. 372. победим, величайшее российское государство не может исчезнуть...

В это трудное для страны время переменились политические позиции эмигрантских деятелей самых разных направлений. После одержанной Красной армией победы в Сталинградской битве, люди, способные нормально рассуждать, верить в победу Германии уже не могли. Многие же начали это понимать значительно раньше. Причем эти процессы коснулись не только русских эмигрантов, но и выходцев из России - эмигрантов других национальностей. По свидетельствам Д.И. Мейснера, патриотический подъем захлестнул не только советскую многонациональную Россию. Так, например, в Словакии во время народного восстания 1944 г. ряд русских эмигрантов принимали активное участие в боевых действиях против фашистов, а к концу войны завершился процесс изживания и крушения специфически эмигрантской политической психологии ${ }^{20}$.

Весьма откровенно и красноречиво в этой связи выступление М. Кедрова к советскому послу: «Буду говорить, г. посол, как офицер, во главе с другими ведший борьбу с Вами. Да, мы были враги... Но годы шли, и наши ряды редели - одни умирали, другие уходили, разочаровавшись в борьбе. Мы же, ведшие борьбу, остались одними ярлыками без содержания. Уже в 1936 - 1937 гг. я и другие начали сознавать, что в России народилось новое поколение, которое не с нами, а с Вами, создается новая государственность, крепнет новая армия - процесс из разрушительного стал созидательным.

Наступила великая война. Советский Союз вначале пошел на соглашение с Германией. Мы, русские за границей, приветствовали это, рассчитывая, что вне процесса войны Россия останется нетронутой и еще более окрепнет. Но в гордыне своей Германия пошла против Советского Союза. Кровавыми слезами мы плакали, когда слышали о первых поражениях, но в глубине души мы продолжали верить, что Советский Союз победит, так как для нас он представлял русский народ. Как Вы правильно отметили, г. посол, что немцам не удалось увлечь за собой нашу эмиграцию - только единицы пошли за ними, мечтая о своих имениях, когда немцы не переставали повторять, что русский народ только и годится, как на удобрение для «великого германского народа». Советский Союз победил Россия спасена, и спасен весь мир. Новая государ-

20 Мейснер Д. И. Миражи и действительность. Записки эмигранта. М., 1966. 
ственность и новая армия оказались необычайно стойкими и сильными, и я с благодарностью приветствую их и их вождей» ${ }^{21}$.

В своем ответе когда-то непримиримым врагам Советской власти посол А.Е. Богомолов подтвердил, что в разных странах мира прокатилась волна патриотизма, захватившая широкие круги эмиграции. Он также отметил те коренные изменения в психологии и поведении эмиграции, которые произошли в годы войны, и вместе с тем подчеркнул разницу между русским и советским патриотизмом: «Последний шире первого, и его сущность заключается не только в любви к России, но и в принятии всех тех изменений, которые в ней произошли» ${ }^{22}$.

Движение помощи советскому народу захватило представителей российской эмиграции разных стран. По данным книги «Русские в Канаде», лучшие люди всех стран стремились оказать Советскому Союзу помощь, чтобы выразить этим свое восхищение и признательность героическому советскому народу. Уже к маю 1942 г. в 26 городах Канады действовало 50 комитетов помощи родине, которые объединились в Федерацию русских канадцев (ФРК), в 1944 г. их число составляло свыше 4 тыс. русских и украинских активистов.

Патриотические инициативы предпринимались также в среде прогрессивной русской эмиграции в США и странах Латинской Америки. Особой популярностью пользовались публичные выступления в университетах Соединенных Штатов Америки В.А. Яхонтова, 60-летнего генерала, еще задолго до войны порвавшего с контрреволюционной эмиграцией. Своим слушателям, американцам и русским эмигрантам, он рассказывал о событиях второй мировой войны, о борьбе советского народа, Красной Армии против фашистских захватчиков, разъяснял освободительный характер этой борьбы, ее значение для судеб всего человечества.

Широкую известность в эмиграции получили выступления генерала А. Деникина. Еще в январе 1938 года в Париже, обращаясь к национальным чувствам своих слушателей и рассуждая о политическом реализме, о значении реальных ценностей в политической борьбе, он называл Гитлера «злей-

21 Шкаренков Л. - Электронный код доступа [URL: http:// scepsis.net/library/id_2136.html]

22 Шкаренков Л. - Электронный код доступа [URL: http:// scepsis.net/library/id_2136.html] шим врагом России и русского народа» ${ }^{23}$. Бывший главнокомандующий вооруженными силами Юга России, один из вождей «белого движения» очень шокировал многих своих соратников, заявив о поддержке Красной Армии, которая должна выступить на защиту родной страны.

Некоторые критики Деникина в эмигрантских кругах совершенно неправомерно сравнивали его позицию с действиями в годы гражданской войны генерала А.А. Брусилова. Будучи русским патриотом, Брусилов, приняв революцию, перешел в Красную Армию и служил Советской России не за страх, а за совесть. А. Деникин, как был контрреволюционером, ярым врагом Советской власти, так им и остался. Но в то же время стоит признать тот факт, что его выступления против угрозы со стороны Германии при всей их непоследовательности в тех условиях способствовали дальнейшему расколу эмиграции, усилению в ее рядах антигитлеровских настроений.

Безусловно, поучительные уроки идейного противостояния зарубежной белой эмиграции, ошибки и заблуждения, имевшие место в процессе поиска формулы согласия и консолидирующей идеи, перспектив объединения различных эмигрантских группировок, их отношение к СССР, к фашизму, к начавшейся Второй мировой войне чрезвычайно актуализируют проблемы политической истории эмиграции в условиях современной российской действительности в контексте глобализированного мира, нуждаются в адекватном историческом осмыслении, и еще на протяжении долгого времени будут оставаться в фокусе внимания исследователей.

Несмотря на многообразие позиций в оценке идейного наследия эмигрантских мыслителей и политических деятелей, их взгляды на специфику узловых моментов российской истории, мы пришли к следующим выводам о том, что российская эмиграция - это уникальное по своим масштабам и последствиям политическое и культурное явление, движущей силой которого явились противоречия, вызванные разным пониманием будущего политического устройства Российского государства и методов достижения заявленных целей.

Несмотря на то, что российская эмиграция в силу социально-политических катаклизм 1917 1922 гг. была разбросана по всему миру, находилась в затруднительных условиях существования, прошла

23 Шкаренков Л. - Электронный код доступа [URL: http:// scepsis.net/library/id_2136.html] 


\section{Международные отношения / International Relations / № 4/2014}

через сложные испытания, тем не менее, она сумела сохранить себя как духовно-культурная целостность.

Острейшим противоречием русской эмиграции явился поиск консолидирующей идеи, который непрестанно вставал на протяжении всего периода эмиграции русского Зарубежья, обеспечивавшей возвращение на Родину, с одной стороны, и упорное отстаивание собственных политических принципов, а зачастую, - настойчивое стремление навязать их большинству, - с другой.

К несомненным заслугам русского Зарубежья можно отнести опыт сохранения языка, культуры, традиций, духовных связей с исторической Родиной, что в современной российской действительности приобретает весомое политическое, социально-психологическое и культурно-историческое звучание.

\section{Библиография:}

1. Бердяев Н.А. Философия творчества, культуры, искусства. Т.2. В 2-х т. М.: Искусство,1994. - 510с. (Серия «Русские философы ХХ века).

2. Бердяев Н.А. Сочинения./Сост., вступ. статья и прим. А.В. Гулыги. - М.: «Раритет», 1994. - 416с. - (Библиотека духовного возрождения).

3. Бердяев Н. Самопознание / Николай Бердяев. - М.: АСТ: Астрель: Политграфиздат, 2010. - 447, [1] с. - (Философия. Психология).

4. Дмитриева Н. - Электронный код доступа [URL: http://scepsis.net/authors/id_92.html;http://yadocent.livejournal. com/344839.html]

5. Ильин И.А. Пути России / Иван Ильин; сост. А.Д. Путинцев. - М.: Вагриус, 2007. - 512 с.

6. Мейснер Д. И. Миражи и действительность. Записки эмигранта. М., 1966.

7. Шкаренков Л. - Электронный код доступа [URL: http://scepsis.net/library/id_2136.html]

8. Овсянникова О.А., Кузнецова А.А. исторические и современные социально-политические основы российского патриотизма // NB: Международные отношения. - 2013. - 3. - C. 87 - 114. DOI: 10.7256/2306-4226.2013.3.9083. URL: http://www.e-notabene.ru/wi/article_9083.html

9. Бочарников И.В. Украинский кризис как элемент пояса стратегического окружения России // NB: Международные отношения. - 2014. - 4. - C. 7 - 32. DOI: 10.7256/2306-4226.2014.4.11617. URL: http://www.e-notabene.ru/wi/ article_11617.html

10. Гушер А.И. Вызовы и угрозы безопасности России // NB: Международные отношения. - 2014. - 1. - C. 64 - 75. DOI: 10.7256/2306-4226.2014.1.10748. URL: http://www.e-notabene.ru/wi/article_10748.html

11. Манойло А.В. Президент Обама и его Континентальная блокада России // NB: Международные отношения. 2014. - 4. - C. 1 - 6. DOI: 10.7256/2306-4226.2014.4.11563. URL: http://www.e-notabene.ru/wi/article_11563.html

12. Манойло А.В. Вооруженный мятеж в Украине: волна цветных революций идет на Россию // NB: Международные отношения. - 2014. - 3. - C. 27 - 35. DOI: 10.7256/2306-4226.2014.3.11498. URL: http://www.e-notabene.ru/wi/ article_11498.html

\section{References (transliterated):}

1. Berdyaev N.A. Filosofiya tvorchestva, kul'tury, iskusstva. T.2. V 2-kh t. M.: Iskusstvo,1994. - 510s. (Seriya «Russkie filosofy XX veka).

2. Berdyaev N.A. Sochineniya./Sost., vstup. stat'ya i prim. A.V. Gulygi. - M.: «Raritet», 1994. - 416s. - (Biblioteka dukhovnogo vozrozhdeniya).

3. Berdyaev N. Samopoznanie / Nikolai Berdyaev. - M.: AST: Astrel': Politgrafizdat, 2010. - 447, [1] s. - (Filosofiya. Psikhologiya).

4. Dmitrieva N. - Elektronnyi kod dostupa [URL: http://scepsis.net/authors/id_92.html;http://yadocent.livejournal. com/344839.html]

5. Il'in I.A. Puti Rossii / Ivan Il'in; sost. A.D. Putintsev. - M.: Vagrius, 2007. - 512 s.

6. Meisner D. I. Mirazhi i deistvitel'nost'. Zapiski emigranta. M., 1966.

7. Shkarenkov L. - Elektronnyi kod dostupa [URL: http://scepsis.net/library/id_2136.html]

8. Ovsyannikova O.A., Kuznetsova A.A. istoricheskie i sovremennye sotsial'no-politicheskie osnovy rossiiskogo patriotizma // NB: Mezhdunarodnye otnosheniya. - 2013. - 3. - C. 87 - 114. DOI: 10.7256/2306-4226.2013.3.9083. URL: http:// www.e-notabene.ru/wi/article_9083.html

9. Bocharnikov I.V. Ukrainskii krizis kak element poyasa strategicheskogo okruzheniya Rossii // NB: Mezhdunarodnye otnosheniya. - 2014. - 4. - C. 7 - 32. DOI: 10.7256/2306-4226.2014.4.11617. URL: http://www.e-notabene.ru/wi/ article_11617.html

10. Gusher A.I. Vyzovy i ugrozy bezopasnosti Rossii // NB: Mezhdunarodnye otnosheniya. - 2014. - 1. - C. 64 - 75. DOI: 10.7256/2306-4226.2014.1.10748. URL: http://www.e-notabene.ru/wi/article_10748.html

11. Manoilo A.V. Prezident Obama i ego Kontinental'naya blokada Rossii // NB: Mezhdunarodnye otnosheniya. - 2014. - 4. C. 1 - 6. DOI: 10.7256/2306-4226.2014.4.11563. URL: http://www.e-notabene.ru/wi/article_11563.html

12. Manoilo A.V. Vooruzhennyi myatezh v Ukraine: volna tsvetnykh revolyutsii idet na Rossiyu // NB: Mezhdunarodnye otnosheniya. - 2014. - 3. - C. 27 - 35. DOI: 10.7256/2306-4226.2014.3.11498. URL: http://www.e-notabene.ru/wi/ article_11498.html 